\title{
Rape in J. M. Coetzee's Fiction: Disgrace, Diary of a bad year and Elizabeth Costello
}

\section{O estupro na ficção de J. M. Coetzee: Desonra, Diário de um ano ruim e Elizabeth Costello}

\author{
Mariana Chaves Petersen 1
}

Mestranda em Letras (Estudos de Literatura) do Programa de Pós-Graduação em Letras da Universidade Federal do Rio Grande do Sul corpo, trauma e memória em tempos de póshumanismo", coordenado pela Profa. Dra. Rita Terezinha Schmidt, e é bolsista da Coordenaçãao de Aperfeiçoamento de Pessoal de Nível Superior. Ja publicou trabalhos sobre literaturas de língua inglesa e crítica feminista, como o artigo Feminism." In: Cadernos do IL v. 49, p. 126-142, 2014.

E-mail: mariana_petersen@hotmail.com
ABSTRACT: Rape is a recurrent motive in J. M. Coetzee's fiction, it being present in novels such as Disgrace (1999), Diary of a bad year (2007) and Elizabeth Costello (2003). This work's objective is to analyze each representation of rape in those novels to discuss the views on violence and disgrace presented. I also relate them to Coetzee's own views such as his vison of what - despite his denial of censorship - might better remain unsaid. In Disgrace, David Lurie sees himself as falling into disgrace after he is charged by the student with whom he had an abrupt affair. Later, his daughter, Lucy, is brutally raped and chooses to keep it as a private affair. She ends up questioning male sexuality as a whole. In Diary of a bad year, Anya believes dishonor to fall over those who raped her, and not over her. However, Señor C disagrees, seeing dishonor as miasma. Finally, in Elizabeth Costello, the protagonist remembers an experience with evil she passed through with a man. She then defends that some things should not be read or written and discusses the risk that writers go through by exploring darker areas of human experience, a view which echoes Coetzee's own.

KEYwoRDS: J. M. Coetzee; Rape; Disgrace; Dishonor.

RESUMO: 0 estupro é um tema recorrente na ficção de J. M. Coetzee, estando presente em romances como Desonra (1999), Diário de um ano ruim (2007) e Elizabeth Costello (2004). O objetivo deste trabalho é analisar cada representação de estupro desses romances para discutir as visões de violência e de desgraça apresentadas, relacionando-as às visões do próprio Coetzee, como a do quê - apesar de ele negar a censura - talvez seja melhor não ser dito. Em Desonra, David Lurie se vê caindo em desgraça após ser acusado pela aluna com quem teve um caso abrupto. Mais tarde, sua filha, Lucy, é brutalmente estuprada e prefere manter o incidente como privado. Ela acaba questionando a sexualidade masculina como um todo. Em Diário de um ano ruim, Anya acredita que a desonra recai sobre aqueles que a estupraram, e não sobre ela. Entretanto, Señor C discorda, vendo a desonra como miasma. Finalmente, em Elizabeth Costello, a protagonista relembra uma experiência com o mal pela qual passou com um homem. Ela então defende que algumas coisas não deveriam ser lidas ou escritas e discute o risco pelo qual escritores passam ao explorar áreas mais sombrias da experiência humana, visão que ecoa a de Coetzee.

Palavras-chave: J. M. Coetzee; Estupro; Desgraça; Desonra. 
"We need to develop ways of speaking about violence in literature which go beyond the safe, exclusive condemnation of certain representations of violence."

(Rosemary Jolly, Colonization, violence, and narration in White South African writing)

"The feel of writing is one of freedom, of irresponsibility, or better, of responsibility toward something that has not yet emerged, that lies somewhere at the end of the road."

(J. M. COETZEE, Doubling the point)

$\mathrm{N}$

obel laureate J. M. Coetzee's works are highly discussed today, and sometimes the author is involved in polemic situations. It has been said, for instance, that Coetzee is not an author to write what is convenient, that he avoids the simplification of reality (cf. PEREIRA, 2015, p. 205), and that one does not find explanations when reading his works (cf. OLIVEIRA, 2015, p. 236). In his novels, one does not find answers but new questions, and, if the reader had any previous belief, there is a great chance of it being shattered after the reading. It has actually been pointed out as a relevant trace in Coetzee's fiction the fact that it dissolves illusions of truth, that it does not offer promises or guarantees (cf. OLIVEIRA, 2015, p. 237). Throughout one of his most famous works, the 1999 Disgrace, there is a feeling that there are no guarantees left. Specifically in this novel, it has been said to be difficult to find simple answers or simplistic opposition of ideas (cf. OLIVEIRA, 2015, p. 247); this text has also been discussed as a denial of previously established truths by presenting rather undesirable truths, which renew the ethical discussion (cf. PEREIRA, 2015, p. 216). To read, interpret and write about Coetzee's fiction we thus have to avoid simplifying it, and try to grasp the philosophical principles that are at stake. Here, I intend to discuss specifically the ideas that the author presents about rape, and its relation to violence, dishonor and silence, in three of his books.

Rape is one of the recurrent motives in Coetzee's fiction, it being present in novels such as the aforementioned Disgrace, Diary of a bad year (2007) and Elizabeth Costello (2003), among others. According to Rosemary Jolly (2009, p. 94), “[t]he acts of rape that Coetzee's fiction depicts involve fantasy on the part of the perpetrators; they are quintessential enactments of desire without responsibility, without regard to or for others." In the novels here examined, this pattern seems to confirm. In Disgrace, there are two rapes represented (though one of them is somehow blurred): when David Lurie, professor of the Cape Technical University, has dubious intercourse with his student, Melanie Isaacs, and later, after David has fallen into "disgrace" and is living with his daughter, Lucy, in a rural area: she is brutally raped in a farm attack, supposedly an assault. The first case has sometimes been questioned as rape, but I will further defend that, if we see it as something other than that, we are being carried away by the narrator's rhetoric. In Diary of a bad year, Anya, who calls herself "Filipina," tells the story of when she and a friend were raped by three American men after they went "for a sail" with them (COETZEE, 2008, p. 29 and p. 96). She tells her story to Señor C, a nickname she has given to the novel's ageing writer with Parkinson's disease, who hires her as a typist. In Elizabeth Costello, the protagonist, whose name gives title to the novel, is-almost? - raped and beaten by a man by whom she "allowed herself to be picked up" (COETZEE, 2004, p. 165) on the street, a man who later tears her clothes apart. I will also discuss how this episode might indeed be considered rape. The consequences of each rape can be summarized as the following: Melanie charges David of sexual harassment - the details of the process remaining unknown to the reader, since David does not allow the committee to read the charges against him-whereas Lucy, who is violently raped by three men, refuses to lay charges against 
them, just telling the police about the robbery. Differently, Anya-whose "voice" we are able to read, in opposition to Melanie-lays charges against her rapists. She discusses the case with Señor C to show him how dishonor did not fall over her, but over her rapists, a view which he refutes. Similarly to Lucy, Elizabeth sees her story as private, it having never been a theme in her fiction.

There are possible parallels between Disgrace and Diary of a bad year. As Kathrin L. Rosenfield and Lawrence Flores Pereira discuss (2015, p. 13), Anya has an individualist and modern comprehension of dishonor, according to which she is freed after laying charges, while Señor C reflects upon the limits of this understanding, invoking situations of extreme violence that befall even the innocents, who are "infected" in a collective disgrace, which the authors call "miasma." Still according to them, the injustices of mythical disgrace may "involve its powerless members in the collective guilt that lastingly affects their personal honor"; ${ }^{1}$ Señor $C$ and Lucy share this feeling of disgrace, in opposition to David Lurie, who does not (ROSENFIELD; PEREIRA, 2015, p. 15, my translation). I would add Elizabeth Costello's episode, her refusal to tell it, in between the two cases, for she does not seem to have fallen into disgrace, though she chooses to remain silent. Melanie's case, however, is controversial, since we have only glimpses of what she says or means. Having this in mind, this work's objective is to analyze each of these representations of rape in order to discuss the views presented on violence and disgrace related to the incidents. Furthermore, by doing so, I also discuss Coetzee's vision of what—despite his effusive denial of censorship—might better remain unsaid.

In the original: "podem envolver seus membros impotentes na culpa coletiva que atinge duradouramente sua honra pessoal” (ROSENFIELD; PEREIRA, 2015, p. 15).

\section{J. M. Coetzee's personae/alter egos and the implied author}

A few of J. M. Coetzee's characters have been said to work as his personae or alter egos. ${ }^{2}$ However, one cannot take Coetzee himself as his characters or narrators. According to narratologist Wayne Booth (1983, p. 151), a novel creates an implicit picture of an author "behind the scenes," an "implied author," which is different from the real person, who creates a "second version" of his or herself while writing. This process creates not only an ideal, impersonal "man in general," but also an implied version of this person that is different from the implied authors of other texts (cf. BOOTH, 1983, p. 70). Booth (1983, p. 71) believes to be inevitable the fact that the reader will try to construct a picture of who is writing, an entity that is not necessarily neutral. This implied version of the author differs from the narrator, the latter being seen by Booth as the speaker in the work in question; furthermore, the implied author might change when one compares more than one work by the same author (cf. BOOTH, 1983, p. 73; p. 71). In Disgrace, as we will discuss, the narrator's and David Lurie's world view do not necessarily match Coetzee's (or at least Coetzee's views in the essays he signed with his own name); it is as if we have an implied author between Coetzee and the novel's narrator. However, according to Herman and Vervaeck (2005, p. 18), there are several problems with this concept of the implied author, which is placed in an intermediate position between text and reader: the latter can even consider the implied author as a reflection of the real author. Coetzee sometimes seems to invite us to this reflection, especially in books such as Elizabeth Costello and Diary of a bad year.

2 Concerning Elizabeth Costello, Rejane Pivetta de Oliveira (2015, p. 248) says that Elizabeth function as Coetzee's "alter ego," while Kathrin L. Rosenfied (2015, p. 102) calls her one of his "personae." In the case of Diary of a bad year, Lucia Helena (2015, p. 275) sees the capital letter of "Señor C" as referring to one of John Coetzee's "fictional alter egos". 
Diary of a bad year is divided in two parts: "Strong Opinions" and "Second Diary." Throughout the novel, the pages are divided in three sections: in the first, we have Señor C's strong opinions and later his second diary; in the second section, there are writings similar to what would be Señor C's diary, in which we see more of his personal impressions; in the third, we have Anya's thoughts when she meets and later works for Señor C. In one of his strong opinions, "On Harold Pinter," Coetzee (which appears to be almost equivalent to the implied author here) seems to give us a hint of what he is doing. Señor $\mathrm{C}$ writes about Harold Pinter, mentioning how when he won the 2005 Noble Prize he was too sick to travel, but recorded a political lecture attacking Tony Blair. He continues:

When one speaks in one's own person-that is, not through one's art- to denounce some politician or other, using the rhetoric of the agora, one embarks on a contest which one is likely to lose because it takes place on ground where one's opponent is far more practised and adept. (COETZEE, 2008, p. 127)

Thus, for a writer of fiction, to use one's own name to write about politics is a battle likely to be lost. What if an author uses a character to do it? In another point of his strong opinions, Señor C writes: "Conventions of discourse require that the writer's existential situation, which like everyone else's is a perilous one, and at every moment too, be bracketed off from what he writes. But why should we always bow to convention?" (COETZEE, 2008, p. 167). Coetzee seems to be confessing that he is "bracketing off" through Señor C, that he has a way of not compromising himself, which would happen if he gave his opinions as "J. M. Coetzee"; he thus expresses them as if they belonged to this specific character. In this case, we have an implied author that seems really close to the own Coetzee, a real person who is unable to be condemned for what he says because it is not he who is saying it, but
Señor C; no one can say that the ideology of the text matches Coetzee's, for the ideology of the implied author is the only one we have access to. However, by the final question of the quote above ("why should we always bow to convention?"), the implied author seems to sign towards giving up convention; it is as if Coetzee is revealing himself to the reader through Señor C: by analyzing this quote, we might say that Coetzee is trying to put himself as incredibly similar to this work's implied author, but without compromise, for he does not sign Señor C's positions as his own. Differently from Harold Pinter, he seems to have created the perfect way of giving his opinions, of implying they are his, while being somehow shielded from criticism, for he can always say that they belong to the character. Amazingly, Señor $C$ has also written a novel called Waiting for the Barbarians (cf. COETZEE, 2008, p. 171), among other similarities. In another of Diary of a bad year's strong opinions, "On paedophilia," Señor C discusses the debates concerning feminism and pornography, especially "[t]he radical feminist attack on pornography, led by such people as Catharine MacKinnon" (COETZEE, 2008, p. 55), a famous name of the anti-pornography movement, as well as of the second-wave radical feminism of the 1980's in general. While MacKinnon believes that pornography leads to a culture of rape, Señor C sees this as not necessarily true and as a form of censorship. In 1996, Coetzee himself published a text entitled "The Harms of Pornography: Catharine MacKinnon," which has its similarities with Señor C's point such as the connection both see between feminism and religious thinking when it comes to pornography. ${ }^{3}$ Coetzee's

${ }^{3}$ In his essays, Coetzee (1996, p. 80-81) highlights the similarities that he sees between the campaign against pornography (specially the case of MacKinnon) and religion: "As narratives of repentance and
conversion, they [the narratives of the campaign against pornography] are structurally indistinguishable conversion, they [the narratives of the campaign against pornography] are structurally indistinguishable from narratives of religious conversion, and therefore tend to bear a heavy if unspoken moral and even religious freight. Thus, in the end it is hard to be sure whether, instead of yoking the energies of American puritanism to a project in gender politics, MacKinnon has not herself been absorbed into the projects of conservative popular religion." Señor C displays a similar perspective in Diary of a bad year with the religious conservatives, and all became confusion" (COETZEE, 2008, p. 54) 
critique will become clearer later in this text, while discussed in relation to MacKinnon's ideas concerning rape.

In Elizabeth Costello, different moments of the writer Elizabeth Costello's life are represented: a few of the lectures she has given, as well as details of personal experience, divided in eight lessons and a postscript. In one of the final lessons, "At the Gate," Elizabeth is asked to make a statement of belief in order to pass through a gate. In her first (rejected) attempt, she writes: "I am a writer, a trader in fictions, [...]. I maintain beliefs only provisionally: fixed beliefs would stand in my way. I change beliefs as I change my habitation or my clothes, according to my needs" (COETZEE, 2004, p. 195, emphasis in the original). This "changing of beliefs" does not necessarily apply to Coetzee, but might be one of the reasons of his different personae or alter egos, each of them somehow echoing something he has written as himself. A few of Elizabeth's concerns such vegetarianism, and desire at an old age find echo in Coetzee's own experience and writings: he is a vegetarian himself; in Diary of a bad year, the old Señor C deeply desires Anya, and Elizabeth Costello also discusses desire in "old folk" (cf. COETZEE, 2004, p. 192). This statement aforequoted gives Elizabeth, a writer, the possibility of changing her mind as she pleases, as well as Coetzee might change from persona to persona, or from implied author to implied author, without compromising himself. The "beliefs" are part of each text and its reception (of how the readers will perceive each implied author), and the real author is kept from possible censorship or personal-directed criticism.

\section{Disgrace}

In the context in which Disgrace was published, the novel was highly criticized. Melanie is described by David as "the dark one" (COETZEE, 2011, p. 18), and Lucy is raped by three black men. In a postapartheid South
Africa, Ian Glenn (2015, p. 133-135) argues, the fact that this is represented in the book was seen as pessimist towards interracial love, befitting conservative uncertainties concerning this sexuality, as well as part of a colonial paradigm. Glenn (2015, p. 141) also sees a portrayal of indifference in relation to the social tensions towards African women, who seem to lack agency in Coetzee's fictional world; David's eroticism does not show any concern for the woman's background, it being only sex-oriented. Though Glenn's argument is relevant to analyze David as a character, I believe that we must differentiate between character, narrator, and the implied author here, the latter clearly ideologically opposing the first two. In spite of the novel's focalization on David, ${ }^{4}$ there seems to be an authorial voice that diverges from the protagonist. Whereas David is a character, the novel has a third person narrator, close to him. In Norman Friedman's (1955, p. 1177) terms, we might call David a selective omniscient narrator, which occurs when "the reader is limited to the mind of only one of the characters. Instead, therefore, of being allowed a composite of viewing angles, he is at the fixed center". Thus, the narrator is only able to see through David's perspective; leaving all the other characters' aside. Furthermore, there is an implied author that seems to diverge from David's and the narrator's perspectives. Differently from the narrator, this authorial voice seems to be critical of David; we might even approximate it to Coetzee's own positions. Carine M. Mardorossian (2011, p. 73) argues that the novel's focus is not to reproduce white middle-class subjectivity, but to "expose the workings of racist ideologies and their inextricable link to gender". She sees that, through his "skillful use of narration", "Coetzee takes a horrific scene of violence [...] as an opportunity to overhaul normative approaches to rape, justice, and human relationships"; the readers are thus invited to question precisely the

${ }_{4}$ David is seen as the focaliser of the novel by Lucy Valerie Graham (2003, p. 440) and Lianne Barnard (2013, p. 19). 
racialized constructions of rape-black on white rape being seen as rape whereas white on white rape being decriminalized (MARDOROSSIAN, 2011, p. 74). Thus, we might say that implied author and reader are connected in the task of questioning precisely what is represented in the novel, as well as David's and the narrator's ideology. Mardorossian (2011, p. 77-79) sees the reader as urged not to identify with David since Disgrace's first sentence; however, she also mentions how the "authorial narrator" and the character's distance is constantly changing, especially in the narration of Melanie's rape, when this distance almost vanishes. Mardorossian does not seem to differ between implicit author and narrator; by making such differentiation in this essay, I believe it is easier to see what happens in such moments: whereas the narrator and David are intertwined in the quote in question, with almost no difference between them, the authorial voice (the implied author) seems to have done this precisely to cause the estrangement necessary to such passage-which I will later discuss in detail. By observing David's lack of tact in relation to Melanie, and the complicity of the narrator, the reader is able to see the implied author as apart from what is happening, almost as if he has managed to create in the reader a repulsion that shows his position-of a critique-in relation to what is being narrated.

Making this narratological differentiation, it is possible to see the novel, as a whole, in consonance with feminist discourses-somehow opposing the events that are represented on it. According to Lianne Barnard (2013, p. 19), "the plot (especially the way rape as a theme is explored in many different variations and narrative situations) makes it possible to read the novel as a feminist critique of male desire, power and willful self-ignorance". In his critique of Catharine MacKinnon's vision on pornography, Coetzee (1996, p. 73) focusses on her "absence of insight into desire as experienced by men". He questions: if he were to write a serious book on power and male desire that shared a thematic with pornography, what would differentiate it from porno- graphy itself? (cf. COETZEE, 1996, p. 72-73). About this hypothesis, Barnard (2013, p. 19) sees Disgrace as the "practice" of this "theory"; she analyses the novel's consonance with radical feminism - of which MacKinnon was a part. Ironically, though sometimes simplistic and dualistic, MacKinnon is a theorist that can help us somehow to enlighten the rape passages present in Disgrace ${ }^{5}$.

In the novel, after having previously had sex with Melanie-though she seemed completely apathetic during it-David goes to her apartment without warning: "she is too surprised to resist the intruder who thrusts himself upon her. When he takes her in his arms, her limbs crumple like a marionette's. [...] 'No, not now!' she says, struggling. 'My cousin will be back!'” (COETZEE, 2011, p. 24-25). However, though "nothing will stop him," he carries her to the bedroom and takes her clothes off:

She does not resist. All she does is avert herself: avert her lips, avert her eyes. She lets him lay her out on the bed and undress her: she even helps him, raising her arms and then her hips. Little shivers of cold run through her; as soon as she is bare, she slips under the quilted counterpane like a mole burrowing, and turns her back on him.

Not rape, not quite that, but undesired nevertheless, undesired to the core. As though she had decided to go slack, die within herself for the duration, like a rabbit when the jaws of the fox close on its neck. So that everything done to her might be done, as it were, far away (COETZEE, 2011, p. 25).

He then has to leave the apartment, for her cousin will be back at any time. The narrator lets us know David's thoughts: "A mistake, a huge mistake. At this moment, he has no doubt, she, Melanie, is trying to cleanse herself of it, of him. He sees her running a bath, stepping into the water, eyes closed like a sleepwalker's" (COETZEE, 2011, p. 25).

5 Though Coetzee sees MacKinnon's opposition between male and female interests as "simplified," even he admits that it is hard not to be "carried along by the verve, the sweep, and the sometimes reckless energy of her attack" (COETZEE, 1996, p. 62). 
One of the first questions we might ask before discussing these passages is: what is rape? The conception of rape varies not only historically, but also geographically. Speaking from the United States' context, MacKinnon (1997, p. 42) says that the law generally "defines rape as intercourse with force or coercion and without consent". In what she calls a "male supremacy," "with force and consent" is redundant: if force is present, it is because consent is absent (cf. MACKINNON, 1997, p. 43). I would go further: when coercion is present, consent is also absent. What we see in Disgrace, in David and Melanie's case, is a man clearly pushing the boundaries until the woman has no way back but accepting to go through with it. He visits her without notice and, without courting of any type, shows what he came for: Melanie did not have a choice even before she let David in; he seemed too determined to stop from the beginning. He then clearly coerces her into having sex with him; and, if he has to do this, it is because consent is absent. It is not as if Melanie's behavior is completely ambiguous; she actually says: “No, not now!”, to what the narrator comments: "But nothing will stop him" (COETZEE, 2011, p. 25). Melanie's (lack of) desire is not a concern for David; she is merely seen as the object of his desire, in the name of "Eros," as he later justifies himself (cf. COETZEE, 2011, p. 52). His Romantic literary insights while with Melanie are completely out of place, and he apparently does not notice what she (does not) want(s): there are signs that she is really not aroused by him, but he proceeds anyway: he wants to fulfill his desire with no responsibility towards its object; as different critics have noticed, he does not see Melanie as an other, with a subjectivity of her own ${ }^{6}$. MacKinnon (1997, p. 45-46) also

${ }^{6}$ According to Graham (2003, p. 438), "Lurie's relationship with Melanie in Disgrace is depicted as betrayal of ethical responsibility, as he violates and will not take responsibility for her as an embodied " he 列 his student: she has a life beyond his desire. says that " $[\mathrm{t}]$ o woman is attributed both the cause of man's initiative and the denial of his satisfaction," in way that consent "becomes more a metaphysical quality of a woman's being than a choice she makes and communicates." When David says to Melanie that a woman's beauty does not belong only to herself, that she has to share it with others ${ }^{7}$ (meaning himself), as well as when he enters her apartment abruptly demanding sex, it is as if Melanie has led him to his initiative; later he sees her as obliged to fulfill him sexually, in spite of herself. Thus, consenting is not a choice for Melanie; it is as if she were able to do nothing but to consent under the circumstances. Considering sexuality as a power relation of gender, MacKinnon (1997, p. 52) says that "consent is a communication under conditions of inequality. It transpires somewhere between what the woman actually wanted, what she was able to express about what she wanted, and what the man comprehended she wanted." In Melanie and David's case, the distinction between rape and intercourse is somehow blurred by the narrator. Rosemary Jolly (2009, p. 99) sees those who do not see it as rape as being carried away by the narrator's rhetoric: "Lurie rapes Melanie, and [...] any other reading of his encounter with her at her flat participates in Lurie's metaphysical delusion that it is 'not quite rape, not that, but undesired nevertheless, undesired to the core'." Indeed, I believe it is difficult not to see this description of intercourse as a depiction of rape; there are several traces of it to go unnoticed. However, if we had access to Melanie's testimony, we might see her own perception of it-which leads to question: how do we legally define rape? Through the victim's testimony?

In accordance with MacKinnon (1997, p. 48), law defines rape according to male sexual terms, and the problem is to distinguish rape from sex in specific cases. The laws on rape are generally phallocentric; if we think of

“[...] a woman's beauty does not belong to her alone. It is part of the bounty she brings into the world. She has a duty to share it" (COETZEE, 2011, p. 16). 
homoerotic sexual relations, for example, adjustments are still beginning to be made concerning the fact that, not only men can rape men, but also that women, according to today's parameters, can rape other women. However, MacKinnon (1997, p. 48) had in mind male-on-female rape; in this case, she says that, since women are socialized to be passive, they might prefer submission to a fight, as well as they might not risk saying "no" when too much force is used. When it comes to passivity as an act of surrender, of not having to fight, it seems to be precisely how Melanie acts in the aforequoted passage of Disgrace. We never have access to her voice beyond her vain attempts to say "no," but she gives other signs that there was no consent and that she is likely to have surrendered to David's desire to avoid a fight. MacKninnon (1997, p. 50) calls attention to the fact that rape is an injury through the female perspective, while it is judged as a crime through the meaning of the act to the accused male. It is also a problem to see whose view constitutes what really happened; to the law, if the rapist did not perceive it as rape, it was not rape, but "rape accusations express one thing men cannot seem to control: the meaning to women of sexual encounters" (MACKINNON, 1997, p. 51). In Disgrace, we never see how the injury was perceived by Melanie, we only know that she was somehow injured because she charges David. However, though she denies being an effective part of the procedure, he has a "trial": for the university, it is not enough what Melanie said; David has to be judged for it to be considered a crime. While they are alone, he seems to get what he wants; however, when Melanie charges him, things go beyond his control: he sees that he did not govern the way Melanie perceived their affair ${ }^{8}$.

\footnotetext{
${ }^{8}$ While the narrator displays David as thinking of Melanie as incapable of taking this step by herself"Melanie would not have taken such a step by herself, he is convinced. She is too innocent for that, too ignorant of her power" (COETZEE, 2011, p. 39)—according to Barnard (2013, p. 24), "Melanie's charge of sexual harassment is a small act of resistance against him."
}

During the inquiry, as José Garcez Ghirardi points out, David goes from possessing discourse to being its object; it is then that he has his first epiphany, when he perceives that "private desire is not absolute" (GHIRARDI, 2015, p. 310, my translation). ${ }^{9}$ His second epiphany takes place when he sees the assaulters' brutality: it is then that he turns to the same institutions that he has previously questioned while being judged (cf. GHIRARDI, 2015, p. 310) ${ }^{10}$. Still to Ghirardi (2015, p. 311), in both cases, Melanie's and Lucy's, the justice system is shown as scant and useless, as unable to take care of relevant moral questions. David's colleagues that are part of his judgment's committee say that he should just make an apology statement to keep his job, which he declines, whereas Lucy refuses to communicate her rape to the police. Differently from Melanie's case, Lucy's rape is not even narrated; what we read are the recollections that David tries to assemble while talking to her. To him, she justifies her denial of seeking authorities:

You want to know why I have not laid a particular charge with the police. I will tell you, as long as you agree not to raise the subject again. The reason is that, as far as I am concerned, what happened to me is a purely private matter. In another time, in another place it might be held to be a public matter. But in this place, at this time, it is not. It is my business, mine alone (COETZEE, 2011, p. 112)

Right after the incident, Lucy refuses to go to the market; David asks her if she is sure of her refusal: "She does not reply. She would rather hide her face, and he knows why. Because of the disgrace. Because of the shame. That is what their visitors have achieved; [...] Like a stain the story is spreading

9 In the original: "o desejo privado não é um absoluto" (GHIRARDI, 2015, p. 307). ${ }^{10}$ During the inquiry, besides justifying himself in the name of Eros, David states: "I am sure the members of this committee have better things to do ware will be no dispute. I plead guilty to both charges. Pass sentence, an 2011 , p. 48). This lack of respect for the inquiry is in opposition to the attempts he would later make
for his daughter to pursue justice. 
across the district. Not her story to spread but theirs: they are its owners" (COETZEE, 2011, p. 115). Melanie's case is made public, though we do not know who decides to do so (Her father? Her boyfriend? Melanie herself?), and the incident makes David fall into disgrace (we never get to know how Melanie feels about herself, whether she also feels "disgraced"). In Lucy's case, her impossibility to erase what happened makes it implausible for her to keep it as absolutely private, although it is her wish. Furthermore, David's conception of how shame operates in the way rape victims feel in relation to public opinion seems to echo Coetzee's own ideas on the theme. In his aforementioned essay on pornography, he examines the topic:

The ambivalence of rape victims - particularly outside the Wes $t$-about seeking redress from the law, and the surprising degree of suspicion or even hostility with which the public, even in the West, treats such plaintiffs, indicates that in matters of honor archaic attitudes are far from dead, that is, that the system of justice of the modern state, based on notions of guilt and innocence, has not entirely supplanted the tribunal of public opinion, based on notions of honor and shame (COETZEE, 1996, p. 80).

Seeking redress from the law is seen as a way to put oneself to the eyes of public opinion and judgement, archaic attitudes that are still present in modern justice. Coetzee's view is very similar to Sorcha Gunne and Zöe Brigley Thompson's; while (re)theorizing rape, they resume an argument on the cases in which victims prefer to say silent:

As in some feminist theory, the victim sees the act of telling her story as a second violation and the members of the court approach her with the critical gaze. The rape narrative is not simply a private story, but a tale to be consumed and appraised in relation to the assumptions already harboured in the watchful audience (GUNNE; THOMPSON, 2010, p. 7).

Therefore, narrating rape to an audience might be felt as being violated again, this time by the others' gaze; it is not enough to have survived it, one has to survive the judgment that seeks to appraise if one was really raped.

In another moment in which Lucy and David discuss what happened to her, she brings the somehow astonishing idea of rape as a tax that she has to pay to remain where she is:

What if... what if that is the price one has to pay for staying on? Perhaps that is how they look at it; perhaps that is how I should look at it too. They see me as owing something. They see themselves as debt collectors, tax collectors. Why should I be allowed to live here without paying? Perhaps that is what they tell themselves (COETZEE, 2011, p. 158).

Rosenfield (2015, p. 121) wonders if Lucy shares the feelings of guilt that ethical young people feel in relation to the apartheid. Is this why Lucy feels she has to pay a debt to be in rural South Africa? A debt due to what her ancestors did to African people in the past? Mardorossian (2011, p. 74) would answer affirmatively; she believes that "Lucy accepts her fate as a symbol of the redistribution of power in postapartheid South Africa". As Gunne and Thompson (2010, p. 6) mention, "the imaginative construction of the nation is often constituted entirely through the image of woman and therefore rape becomes an ideological weapon for both the colonizing and colonized male." In both contexts, the raping of African women by colonizers as well of white women by colonized men are violations of female bodies, whose rape has historically been seen as an equivalent of conquering the land, and exposing this colonial violence has been one of Coetzee's fiction's recurrent themes ${ }^{11}$. Moreover, it is inevitable to draw a parallel between what happens to Lucy and Melanie. According to Mardorossian (2011, p. 80), by doing so "Coetzee highlights how the critical attention paid to black on

Graham (2003, p. 442) mentions: "Mapping female bodies onto the landscape, colonialism propagated myth of territories as 'virgin land', but Coetzee's fiction exposes the violence literally inflicted on bodies in the colonial encounter." 
white sexual violence in the charged context of postapartheid South Africa masks its link to the similar forms of more or less naturalized violence perpetuated in white liberal contexts." While Lucy's denouncement of the sexual violence she has suffered would have probably created new instances of white fear and racism, David's raping of Melanie, herself a black woman, is somehow naturalized; though he falls into disgrace, it happens as if it were a case of sexual harassment rather than rape. Despite completely changing his life-for worse-arresting David is not shown as an option in the novel.

One of the other few things that Lucy mentions is the personal hatred that she felt during the act. She tries to analyze it in a bigger scale, questioning her father, as a male:

Hatred... When it comes to men and sex, David, nothing surprises me any more. Maybe, for men, hating the woman makes sex more exciting. You are a man, you ought to know. When you have sex with someone strangewhen you trap her, hold her down, get her under you, put all your weight on her-isn't it a bit like killing? Pushing the knife in; exiting afterwards, leaving the body behind covered in blood-doesn't it feel like murder, like getting away with murder? (COETZEE, 2011, p. 158).

Lucy questions if violence is not an ingrained part of male sexuality. Do men feel more pleasure when it is "a bit like killing"? when they "get away with murder"? MacKinnon (1997, p. 44) mentions that violence is seen as present in "acceptable sex," and while some feminists see rape as an act of violence, not sexuality, others do see violence as integrated in male sexuality. Despite MacKinnon criticism of the first view, I believe sex and violence can be separated. She says that violence does not make rape less sexual (for the rapist), it can make it be even more sexual, since coercion has become "integral to male sexuality" (MACKINNON, 1997, p. 44). I think that, structurally, male sexuality and coercion are generally linked, but there are ways out of this practice; the problem is that insistence, coercion, is seen as common male flirting and courting. Clearly, it does not have to be like this. However, Lucy seems to echo MacKinnon's belief; she seems to think that male sexuality and violence are intertwined. Later in the novel, David is able to put himself in the rapists' shoes, imagining how they could have proceeded, ${ }^{12}$ which is in consonance with Lucy's argument.

\section{Diary of a bad year}

If in Disgrace there is a woman who chooses silence and another that does speak but whose voice is omitted from the novel's pages, in Diary of a bad year Anya refuses to keep the rape experience as private, and we, as readers, have access to her narrative, through which she refuses the role of victim. Nevertheless, Señor C seems to view shame similarly to how David sees it befalling Lucy, or as alive as the own Coetzee sees the honor archaic attitudes. At a certain moment of the narrative, Anya brings the topic of dishonor, which she picks from one of Señor C's texts she has typed, to discuss with him. To prove her point, she tells the story of when she and a friend were raped. They accept to go to the yacht of three American men that they have just met:

[...] I won't go into the details but there were three of them and two of us, and they must have decided that we were just a couple of bimbos, a couple of putas, whereas they were sons of doctors and lawyers and what have you, they were taking us cruising on the Caribbean, so we owed them, so they could do what they liked with us. Three of them. Three strapping young males (COETZEE, 2008, p. 97)

${ }^{12}$ David supposes what Lucy went through: "This is not happening, she said to herself as the men forced her down it is just a dream a nightmare. While the men, for their part drank up her fear revelled in it did all they could to hurt her to menace her to heighten her terror. Call your dogs! they said to her. Go on, call your dogs! No dogs? Then let us show you dogs! / [ Lucy's intuition is right after all: he Go on, call your dogs! No dogs? Then let us show you dogs! / [...] Lucy's intuition is right after all: he does understand; he can, if he concentrates, if he loses himself, be there, be the men, inhabit them, fill them with the ghost of himself. The question is, does he have it in him to be the woman?" (COETZEE, 
After a day there, she and her friend try to jump overboard, and are later dumped in a fishing village. Anya then mentions how the men were wrong to imagine that their "adventure" would end up like this: when the women get back to Cancún (where they previously were), they lay charges against them: the men are arrested at their next port, and "they were in deep shit" (COETZEE, 2008, p. 99). Anya mentions that, when they got to the police station, the police captain asked whether they were sure they wanted to make their story public, "because, you know, dishonour, infamia, is like bubble gum, wherever it touches, it sticks" (COETZEE, 2008, p. 100). However, Anya could not disagree more with him; she recalls what she told him at the time: "This is the twentieth century, capitano (it was still the twentieth century then). In the twentieth century, when a man rapes a woman it is the man's dishonour. The dishonour sticks to the man, not to the woman. At least that is how it is where I come from" (COETZEE, 2008, p. 101-102). She explains why she believes that Señor C was wrong about dishonor:

When you tell me you walk around bent under your load of dishonour, I think of those girls from the old days who had the bad luck to get raped and then had to wear black for the rest of their lives [...] You have got it wrong, Mister C. Old thinking. [...] Abuse, rape, torture, it doesn't matter what: the news is, as long as it isn't your fault, as long as you are not responsible, the dishonour doesn't stick to you (COETZEE, 2008, p. 103-105).

After Anya has made her point, Señor C defends his:

No man is an island, [...]. We are all part of the main, [...]. Things haven't changed, mistress Anya. Dishonour won't be washed away. Won't be wished away. Still has its old power to stick. Your three American boys-I have never laid my eyes on them, but they dishonour me nevertheless. And I would be very surprised if in your inmost depths they did not continue to dishonour you (COETZEE, 2008, p. 107-111).
To his point, Anya responds with sudden rage: “Don't you tell me how I feel! [...] What do you know!" (COETZEE, 2008, p. 115). It seems that Señor $\mathrm{C}$ means that what they did was so shameful that it would dishonor anyone who knew about the story, or was part of it; it does not necessarily mean that Anya must feel dishonored for having been raped, which is what she seems to understand and why she appears to be so offended: she has mentally worked not to feel shame for something that happened to her, something of which she had no control, and she sees Señor C as trying to take that away from her.

It is much easier for us to sympathize with Anya's argument; her logic makes it possible for a person to pass through a traumatic experience and still be able to live his or her life later. Anya denies being a victim of rape; she does not want to be defined by her rape, dishonored or shamed by it throughout her life. Gunne and Thompson (2010, p. 3) see the breaking with the victim/perpetrator binary as a new direction in theorizing rape, and Anya seems to be a fictional example of this rupture. Frances Ferguson (1987, p. 97) comments that there seems to be a link between a woman's powerlessness and the truthfulness of her testimony; if she becomes powerful, her testimony loses its strength. Anya is not only getting rid of her shame when she places it entirely on the rapists, she is also getting rid of her own powerlessness, of which Señor C, as a listener, seems to be skeptical.

Anya is actually right when she says that Señor C has an "old thinking": indeed his logic is much older than hers. In the strong opinion "On the curse," he discusses curse since ancient Greek religion (cf. COETZEE, 2008, p. 47). He quotes from Jean-Pierre Vernant, who explains tragic guilt:

Tragic guilt takes place in the constant clash between the ancient religious conception of the misdeed as a defilement attached to an entire race and inexorably transmitted from one generation to the next..., and the new concept adopted in law according to which the guilty one is defined as a private individual who, acting under no constraint, has deliberately chosen to commit a crime (VERNANT, 1990 apud COETZEE, 2008, p. 49). 
While Anya follows the new concept, by placing guilt in an individual who committed a crime, Señor C seems to be founder of Vernant's "tragic guilty," which passes from one person to a whole race or even through generations. Vernant's concept is very similar to Robert Parker's (1996, p. 13) study on miasma - though the latter discusses the problems of relying only on tragic texts as miasma's only sources. Parker (1996, p. 1) mentions that pollution is a common presence in Greek texts in general; in tragedy, it is shown as a great concern: it was believed to be able to spread all over Greece and through different generations of a family. Parker differentiates between "miasma" and "agos": whereas miasma usually leads a person to a condition of impurity, it being contagious and possible to be associated with dirt, agos is generally a kind of miasma related to divine power, it having a source in sacrilegious acts (1996, p. 3-5; p. 8-9). Interestingly, Parker mentions the term "disgrace." While discussing the case of the Alcmaeonids, who were seen as polluted and thus exiled from and later reinstated in Athens, he comments that, "[i]n this case, it seems that pollution had soon ceased to be an actual source of religious anxiety, and become instead an inherited disgrace, one factor among others in the general reputation of the family, which enemies would denounce and friends ignore" (PARKER, 1996, p. 17, emphasis added). Therefore, Señor C's conception of dishonor, of disgrace, is indeed similar to the "old thinking" of miasma-which is relatable to the way David sees his daughter as falling into disgrace/shame. However, though old, Señor C's logic seems to be very up-to-date in an example he giveswhich to me, as a woman, is more acceptable than that of Anya's rape. If Lucy feels guilty for being a descendent of South African colonizers, in a similar way, Señor C updates the idea of "curse" by mentioning how it passes from one generation to the other in the case of the Germans and Nazism: "Young Germans protest, We have no blood on our hands, so why are we looked on as racist and murderers? The answer: Because you have the misfortune to be the grandchildren of your grandparents; because you carry a curse" (COETZEE, 2008, p. 50). If one would follow Anya's logic, once the murderers were judged, no descendant would have to feel dishonored-which seems rather unlikely in this case.

\section{Elizabeth Costello}

Elizabeth Costello is in consonance with Lucy's view of her rape as private, as hers alone, as well as with Coetzee's personal opinions, which I will also discuss. Elizabeth is-almost?-raped. This story happened when she was still young. Through the novel's third person narrator, we come to know what happened to her when she let herself be picked up on the street by “Tim or Tom":

[...] at the last minute she could not go through with it. "I'm sorry," she said "I'm really sorry, can we stop." But Tim or Tom would not listen. When she resisted, he tried to force her. For a long time, in silence, panting, she fought him off, pushing and scratching. To begin with he took it as a game. Then he got tired of that, or his desire tired, turned to something else, and he began to hit her seriously. He lifted her off the bed, punched her breasts, punched her in the belly, hit her a terrible blow with his elbow to her face. When he was bored with hitting her he tore up her clothes and tried to set fire to them in the waste-paper basket. Stark naked, she crept out and hid in the bathroom on the landing. [...]

It was her first brush with evil. She had realized it was nothing less than that, evil, when the man's affront subsided and a steady glee in hurting her took its place. He liked hurting her, she could see it; probably liked it more than he would have liked sex. (COETZEE, 2004, p. 165)

A feminist analysis of this passage would probably say that Elizabeth was also raped; at least, being beaten so violently and having one's clothes tore up certainly qualify as a traumatic experience. According to MacKinnon (1997, p. 49), such analysis would show that battery is not so different from 
rape, "not because both are violent but because both are sexual." She states that "sexuality is violent, so perhaps violence is sexual" (MACKINNON, 1997, p. 49). The fact that violence can be sexual is clear in the passage: "Tim or Tom" appears to see battery as sexual; Elizabeth even believes him to like it more than sex. Thus, she senses that it was a "brush with evil"; what else could she call it?

The old Elizabeth recalls the event as "-really-unimportant" in her life (COETZEE, 2004, p. 166). She asks herself why she would remember it at that time, and answers:

because she has never revealed it to anyone, never made use of it. [...] Unless Tim or Tom himself has survived into doddering old age, unless the committee of angelic observers has saved the minutes of the proceedings of that night, what happened in the rooming house belongs to her and her alone. [...] She finds it good, it pleases her, this silence of hers, a silence she hopes to preserve to the grave (COETZEE, 2004, p. 166)

Similarly to Lucy, Elizabeth sees her experience as private, as something that belongs only to her. In fact, after the recollections of the event, we come to know that "she no longer believes that storytelling is good in itself" (COETZEE, 2004, p. 167); it is then that she mentions how some things should remain unsaid: "it is silent on the life the genie leads shut up in the bottle. It merely says that the world would be better off if the genie remained imprisoned" (COETZEE, 2004, p. 167).

The "unimportance" that Elizabeth says the event had might be a key point if we attempt a reading in terms of trauma. According to Cathy Caruth (2006, p. 2), " $[t]$ he demand to find a language for trauma is thus a paradoxical obligation to speak without burying the silence at the heart of the story, to find a language that bears within it, although it does not submit to, the silencing power of the event." Interestingly, in spite of Elizabeth saying that the experience is hers alone, it is not buried: we, as readers, are made aware of it; there is, in fact, a language that brings it to knowledge. And why would Elizabeth recall this event after so many years? Her theory on how some genies should be kept imprisoned is built after she reads a book written by Paul West, a novel about the Nazi period that recounts the execution of the July 1944 plotters. It is then that she recalls her experience with sexual violence. This can be related to how Caruth $(2006$, p. 2) sees " $[t]$ he temporality of trauma-the delay of the event that always returns elsewhere, in another place and time." West's book is so violent that Elizabeth is brought back to that moment, which she had not yet wanted to inhabit again. It is then that she starts to believe that "certain things are not good to read or to write" (COETZEE, 2004, p. 173, emphasis in the original), as she says in her lecture on the theme. She sees these risks especially when it comes to the artist: "I take seriously the claim that the artist risks a great deal by venturing into forbidden places: risks, specifically, himself; risks, perhaps, all" (COETZEE, 2004, p. 173). This echoes one of Coetzee's own opinions, from his essay on MacKinnon. At a certain point, he states:

the desire for freedom is devious, does not fully know itself, cannot afford to fully know itself. Neither legal bans on pornographic representation nor the chilling climate of censure or social disapproval of which MacKinnon shows herself well aware will prevent serious writers from exploring the darker areas of human experience. The question is simply: at what cost to them; and do we want to add to that cost? (COETZEE, 1996, p. 74).

Coetzee believes that a writer's desire to explore the "darker areas of human experience" must be free of censure. Nevertheless, like Elizabeth, he questions to what cost he or she undergoes such exploration. In accordance with Elizabeth, we might question: would it not be better to keep the genie in the bottle? is it worth releasing him? According to Jolly (2009, p. 108), because Elizabeth and Lucy are seen as contaminated by shame rather than those who inflicted evil upon them, silence would seem valuable; she 
concludes that "the risk of betrayal, rather than that of censorship, appears to drive Coetzee's pleas for certain silences." In those two cases, the women prefer the genie to remain imprisoned. Who has the right to tell them not to do so? who, other than the two, knows the cost to release him?

Though it is impossible for others to see the costs to the writer when writing about those "darker areas," or to a victim of rape when talking about this traumatic experience, I still believe in the importance of not burying the story, of not silencing it. Elaine Scarry (1985, p. 172-173) sees the act of describing one's hurt in an image of agency as the act of creating an object that can finally be seen as separated and thus lifted away from the body, carrying part of the pain with it. The desire to write one's story or to confess one's experience, whether it will be better or worse for a certain person, whether the cost is worth it, is a decision of this person alone. However, as we cannot oblige one to return to a dark experience, an experience with "evil," we also cannot defend the silencing of those who do have a desire to speak or write about it.

\section{References}

BARNARD, Lianne. The politics of rape: traces of radical feminism in Disgrace by J. M. Coetzee. In: Tydskrif vir Letterkunde, v. 50, n. 2, p. 19-28, 2013. Available at: <http://www. ajol.info/index.php/tvl/article/view/93208/82621>. Accessed: 20 May 2016.

BOOTH, Wayne C. The rhetoric of fiction Chicago: The University of Chicago Press, 1983.

CARUTH, Cathy. An introduction to "Trauma, Memory, and Testimony". Reading on: a journal of theory and criticism, Issue 1: Trauma, Memory and Testimony. Emory University, Fall 2006, p. 2. Available at: <http://readingon.library.emory.edu/issue1/ articles/Caruth/RO\%20-\%202005\%20-\%20Caruth.pdf>. Accessed: 14 Jan. 2015.

COETZEE, J. M. Diary of a bad year (2007). London: Vintage Books, 2008.

Disgrace (1999). London: Vintage Books, 2011.
Elizabeth Costello (2003). London: Vintage Books, 2004.

. The harms of pornography: Catharine MacKinnon. In: essays on censorship. Chicago: University of Chicago Press, 1996

Giving offense

FERGUSON, Frances. Rape and the rise of the novel. In: Representations, n. 20, Special Issue: Misogyny, Misandry, and Misanthropy, p. 88-112, Autumn 1987. Available at: <http://www.jstor.org/stable/2928503>. Accessed: 7 May 2016.

FRIEDMAN, Norman. Point of view in fiction: the development of a critical concept, PMLA v. 70, n. 5, p. 1160-1184, Dec. 1955. Available at: <http://www.jstor.org/stable/459894>. Accessed: 10 May 2016.

GHIRARDI, José Garcez. Desde que eu não tenha que me transformar em uma pessoa melhor: o sem-sentido moral do direito em Desonra de J. M. Coetzee. In: ROSENFIELD, Kathrin H.; PEREIRA, Lawrence Flores (Ed.). Lendo J. M. Coetzee. Santa Maria: Ed. da UFSM, 2015. p. 303-314.

GLENN, Ian. Partiu para sempre - Desonra, de Coetzee. Translated by Elaine Barros Indrusiak. In: ROSENFIELD, Kathrin H.; PEREIRA, Lawrence Flores (Ed.). Lendo J. M. Coetzee. Santa Maria: Ed. da UFSM, 2015.

GRAHAM, Lucy Valerie. reading the unspeakable: Rape in J. M. Coetzee's Disgrace, Journal of Southern African Studies, v. 29, n. 2, p. 433-444, June. 2003. Available at: <http://searchebscohost-com.ez45.periodicos.capes.gov.br/login.aspx? direct=true \&db=aph\&AN=9930425 \&lang=pt-br\&site=ehost-live\&authtype=ip,cookie,uid $>$. Accessed: 3 Jan. 2016.

GUNNE, Sorcha; BRIGLEY THOMPSON, Zöe. Feminism without borders: The potentials and pitfalls of re-theorizing rape. In (Ed.). Feminism, literature and rape narratives: violence and violation. New York: Routledge, 2010.

HELENA, Lucia. Cristais da Memória em J. M. Coetzee: Reflexões em torno do estar à margem e do paradox em Diário de um ano ruim. In: ROSENFIELD, Kathrin H.; PEREIRA, Lawrence Flores (Ed.). Lendo J. M. Coetzee. Santa Maria: Ed. da UFSM, 2015.

HERMAN, Luc; VERVAECK, Bart. Handbook of narrative analysis (2001). Lincoln: University of Nebraska Press, 2005.

JOLLY, Rosemary. Writing desire responsibly. In: BOEHMER, Elleke; EAGLESTONE, Robert; IDDIOLS, Katy (Ed.). J. M. Coetzee in Context and Theory. London: Continnum, 2009.

MACKINNON, Catharine A. Rape: On Coercion and Consent (1989). In: COMBOY, Katie MEDINA, Nadia; STANBURY, Sarah (Ed.). Writing on the Body: female embodiment and feminist theory. New York: Columbia University Press, 1997. 
MARDOROSSIAN, Carine M. Rape and the violence of representation in J. M. Coetzee's Disgrace, Research in African literatures, v. 42, n. 4, p. 72-83, Winter 2011. Available at: <http://muse.jhu.edu/journals/ral/summary/v042/42.4.mardorossian.html>. Accessed: 3 Jan. 2016.

OLIVEIRA, Rejane Pivetta de. Mal-estar da cultura e ética da linguagem em Desonra, de J. M. Coetzee. In: ROSENFIELD, Kathrin H.; PEREIRA, Lawrence Flores (Ed.). Lendo J. M. Coetzee. Santa Maria: Ed. da UFSM, 2015.

PARKER, Robert. Introduction. In: __. Miasma: Pollution and purification in early Greek religion (1983). Oxford: Clarendon Press, 1996.

PEREIRA, Lawrence Flores. A publicação de Disgrace, de J. M. Coetzee e a Submissão do Congresso Nacional Africano de Direitos Humanos: os farm attacks, a AIDS, os temores brancos e as tentações da censura. In: ROSENFIELD, Kathrin H.; (Ed.). Lendo J. M. Coetzee. Santa Maria: Ed. da UFSM, 2015. p. 189-226.

ROSENFIELD, Kathrin H. Ambiguidade moral e ficcional em Desgraça/Desonra. In: ROSENFIELD, Kathrin H.; PEREIRA, Lawrence Flores (Ed.). Lendo J. M. Coetzee. Santa Maria: Ed. da UFSM, 2015

ROSENFIELD, Kathrin H.; PEREIRA, Lawrence Flores. Apresentação. In: (Ed.). Lendo J. M. Coetzee. Santa Maria: Ed. da UFSM, 2015.

SCARRY, Elaine. Pain and imagining. In: The body in pain: The making and unmaking of the world. New York: Oxford University Press, 1985. 